\title{
Front Matter: Volume 10369
}

, "Front Matter: Volume 10369," Proc. SPIE 10369, Thermal Radiation Management for Energy Applications, 1036901 (14 December 2017); doi: $10.1117 / 12.2295635$

SPIE Event: SPIE Optical Engineering + Applications, 2017, San Diego, California, SPIE. United States 


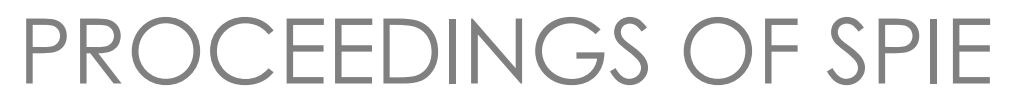

\section{Thermal Radiation Management for Energy Applications}

Peter Bermel

Mowafak M. Al-Jassim

Editors

9-10 August 2017

San Diego, California, United States

Sponsored and Published by

SPIE 
The papers in this volume were part of the technical conference cited on the cover and title page. Papers were selected and subject to review by the editors and conference program committee. Some conference presentations may not be available for publication. Additional papers and presentation recordings may be available online in the SPIE Digital Library at SPIEDigitalLibrary.org.

The papers reflect the work and thoughts of the authors and are published herein as submitted. The publisher is not responsible for the validity of the information or for any outcomes resulting from reliance thereon.

Please use the following format to cite material from these proceedings:

Author(s), "Title of Paper," in Thermal Radiation Management for Energy Applications, edited by Peter Bermel, Mowafak M. Al-Jassim, Proceedings of SPIE Vol. 10369 (SPIE, Bellingham, WA, 2017) Seven-digit Article CID Number.

ISSN: 0277-786X

ISSN: 1996-756X (electronic)

ISBN: 9781510611955

ISBN: 9781510611962 (electronic)

Published by

SPIE

P.O. Box 10, Bellingham, Washington 98227-0010 USA

Telephone +1 3606763290 (Pacific Time) · Fax +1 3606471445

SPIE.org

Copyright @ 2017 , Society of Photo-Optical Instrumentation Engineers.

Copying of material in this book for internal or personal use, or for the internal or personal use of specific clients, beyond the fair use provisions granted by the U.S. Copyright Law is authorized by SPIE subject to payment of copying fees. The Transactional Reporting Service base fee for this volume is $\$ 18.00$ per article (or portion thereof), which should be paid directly to the Copyright Clearance Center (CCC), 222 Rosewood Drive, Danvers, MA 01923. Payment may also be made electronically through CCC Online at copyright.com. Other copying for republication, resale, advertising or promotion, or any form of systematic or multiple reproduction of any material in this book is prohibited except with permission in writing from the publisher. The CCC fee code is 0277 $786 \times / 17 / \$ 18.00$.

Printed in the United States of America.

Publication of record for individual papers is online in the SPIE Digital Library.

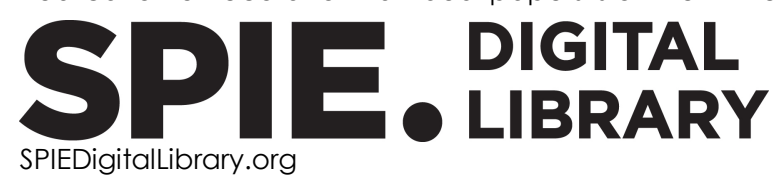

Paper Numbering: Proceedings of SPIE follow an e-First publication model. A unique citation identifier (CID) number is assigned to each article at the time of publication. Utilization of CIDs allows articles to be fully citable as soon as they are published online, and connects the same identifier to all online and print versions of the publication. SPIE uses a seven-digit CID article numbering system structured as follows:

- The first five digits correspond to the SPIE volume number.

- The last two digits indicate publication order within the volume using a Base 36 numbering system employing both numerals and letters. These two-number sets start with 00, 01, 02, 03, 04, 05, 06, 07, 08, 09, OA, OB ... 0Z, followed by 10-1Z, 20-2Z, etc. The CID Number appears on each page of the manuscript. 


\title{
Contents
}

\author{
$\checkmark \quad$ Authors \\ vii Conference Committee \\ ix Introduction
}

SOLAR THERMAL SELECTIVE ABSORBERS

1036905 Spectral splitting for thermal management in photovoltaic cells [10369-4]

NOVEL EXPERIMENTS IN RADIATIVE COOLING

10369 OA Super-cool paints: optimizing composition with a modified four-flux model [10369-9]

10369 OB 3D printable optical structures for sub-ambient sky cooling [10369-10]

NOVEL CONCEPTS IN RADIATIVE COOLING

10369 OD Radiative cooling for concentrating photovoltaic systems [10369-12]

10369 OE Structure optimization of metallodielectric multilayer for high-efficiency daytime radiative cooling [10369 9-13]

NOVEL APPLICATIONS FOR THERMAL RADIATION

10369 OF High performance incandescent lighting using a selective emitter and nanophotonic filters (Invited Paper) [10369-14]

10369 OG Nanostructure enhanced near-field radiative heat transfer and designs for energy conversion devices [10369-15]

$10369 \mathrm{OH}$ Fabrication and thermal analysis of micro thermocouples for energy harvesting [10369-16] 
Proc. of SPIE Vol. $103691036901-4$ Downloaded From: https://www.spiedigitallibrary.org/conference-proceedings-of-spie on 26 Apr 2023
Terms of Use: https://www.spiedigitallibrary.org/terms-of-use 


\section{Authors}

Numbers in the index correspond to the last two digits of the seven-digit citation identifier (CID) article numbering system used in Proceedings of SPIE. The first five digits reflect the volume number. Base 36 numbering is employed for the last two digits and indicates the order of articles within the volume. Numbers start with 00, 01, 02, 03, 04, 05, 06, 07, 08, 09, 0A, OB...0Z, followed by 10-1Z, 20-2Z, etc.

Alam, Muhammad Ashraful, OD

Almansouri, lbraheem, 05

Apostoleris, Harry, 05

Arnold, Matthew D., OA, OB

Bermel, Peter, OD

Bhatia, Bikram, OF

Chiesa, Matteo, 05

Chiou, Yu-Cheng, 05

Gali, Marc A., OA

Gentle, Angus R., OA, OB

González, Francisco Javier, $\mathrm{OH}$

González, Gabriel, $\mathrm{OH}$

Hayashi, Yasuhiko, OE

llic, Ognjen, OF

Ishikawa, Atsushi, OE

Jin, Xin, OD

Leroy, Arny, OF

Lin, Chungwei, OG

Mora Ventura, B., $\mathrm{OH}$

Nuhoglu, A., OB

Smith, Geoffrey B., OA, OB

Soljačić, Marin, OF

Suichi, Takahiro, OE

Sun, Xingshu, OD

Sun, Yubo, OD

Teo, Koon Hoo, OG

Tsuruta, Kenji, OE

Wang, Bingnan, OG

Wang, Evelyn N., OF

Wilke, Kyle, OF

Zhou, Zhiguang, OD 
Proc. of SPIE Vol. $103691036901-6$

Downloaded From: https://www.spiedigitallibrary.org/conference-proceedings-of-spie on 26 Apr 2023 Terms of Use: https://www.spiedigitallibrary.org/terms-of-use 


\title{
Conference Committee
}

\author{
Program Track Chair
}

Oleg V. Sulima, GE Global Research (United States)

Conference Chairs

Peter Bermel, Purdue University (United States)

Mowafak M. Al-Jassim, National Renewable Energy Laboratory (United States)

Conference Program Committee

Partha Dutta, Rensselaer Polytechnic Institute (United States)

\section{Session Chairs}

1 Solar Thermal Selective Absorbers

Mowafak M. Al-Jassim, National Renewable Energy Laboratory (United States)

Peter Bermel, Purdue University (United States)

2 High-Temperature Metamaterials

Peter Bermel, Purdue University (United States)

Zongfu Yu, University of Wisconsin-Madison (United States)

3 Novel Experiments in Radiative Cooling

Mowafak M. Al-Jassim, National Renewable Energy Laboratory (United States)

Peter Bermel, Purdue University (United States)

4 Novel Concepts in Radiative Cooling

Peter Bermel, Purdue University (United States)

Zubin Jacob, Purdue University (United States)

5 Novel Applications for Thermal Radiation

Mowafak M. Al-Jassim, National Renewable Energy Laboratory (United States)

Katherine Fountaine, Northrop Grumman Aerospace Systems (United States) 
Proc. of SPIE Vol. 10369 1036901-8

Downloaded From: https://www.spiedigitallibrary.org/conference-proceedings-of-spie on 26 Apr 2023 Terms of Use: https://www.spiedigitallibrary.org/terms-of-use 


\section{Introduction}

The inaugural symposium for Thermal Radiation Management for Energy Applications sought to capture the diverse roles that thermal radiation can play in many sustainable energy systems. In this context, achieving control over thermal radiation offers many novel phenomena, such as enhancing or suppressing emission through novel physical mechanisms at selected wavelengths, angles, or polarizations. Recent developments in material science, nanophotonics, plasmonics, and metasurfaces have made this a uniquely promising time to develop new understanding and capabilities in this direction. These new capabilities can then find clear applications across a range of fields.

The primary areas covered in this year's symposium were selective solar thermal absorbers; high-temperature metamaterials; radiative cooling; and novel applications for thermal radiation.

Selective solar thermal absorbers allow for one to capture sunlight while minimizing thermal re-radiation, improving the operating temperature and the overall conversion efficiency of solar thermal devices. Particular highlights include generalized theory of selective solar absorber design (Shen et al.) and solar absorbers for steam generation and water purification (Jia Zhu et al.).

High-temperature metamaterials have value in terms of creating more efficient and selective infrared sources, which can be used by themselves or coupled with thermophotovoltaics to generate electric power from heat. Novel work presented used graphene as the basis for selective thermal emission using gap plasmon modes with voltage tuning (Kate Fountaine et al.), as well as in combination with epsilon-near-zero materials (Zubin Jacob et al.)

Another key area requiring careful control of thermal radiation is radiative cooling, whether for terrestrial or space-based applications. Radiative cooling allows both for daytime passive cooling above and beyond standard convective processes, as well as below-ambient cooling for night time power generation. Significant work presented showed a mass-manufacturable path for radiative coolers based on nanostructured polymers (Xiaobo Yin et al.), as well as paints (Marc Gali et al.) and 3D-printed structures (A. Gentle et al.).

Finally, novel applications for thermal radiation were covered, which included more efficient incandescent lighting (Leroy et al.), thermoradiative conversion of heat to electricity (Bingnan Wang et al.), and 24\%-efficient thermophotovoltaics (Woolf et al.).

In summary, this inaugural symposium on achieving control over thermal radiation explored several multi-faceted, multidisciplinary problems that impact both basic 
science and practical applications. This effort has set the stage for exploring the role of additional novel materials with even higher potential performance at both near-ambient and highly-elevated temperatures, as well as developing further connection and scaling of these techniques to use in practical applications.

Peter Bermel Mowafak M. Al-Jassim 